\title{
MOTIVASI PESERTA DIDIK DALAM MENGIKUTI KEGIATAN EKSTRAKULIKULER TAEKWONDO DI SMK NEGERI 1 SINGARAJA
}

\author{
Hendra Gunawan Nababan ${ }^{1}$, Wahjoedi. ${ }^{2}$, Ni Luh Putu Spyanawati ${ }^{3}$ \\ Prodi Pendidikan Jasmani Kesehatan dan Rekreasi \\ Jurusan Pendidikan Olahraga \\ Fakultas Olahraga dan Kesehatan \\ Universitas Pendidikan Ganesha \\ e-mail: $\frac{\text { Hendranababan58@gmail.com } 1 \text {, Wahjoedi@undiksha.ac.id² }}{\text { putu.spyanawati@undiksha.ac.id }}$,
}

\begin{abstract}
Abstrak
Penelitian ini bertujuan untuk mengetahui seberapa besar motivasi peserta didik dalam mengikuti ekstrakulikuler taekwondo di SMK Negeri 1 Singaraja tahun 2020. Jenis penelitian ini adalah deskriptif dengan pendekatan kuantitatif. Populasi dalam penelitian ini adalah peserta ekstrakurikuler taekwondo berjumlah 30 orang. Teknik pengambilan sampel menggunakan teknik total sampling. Analisis data dalam penelitian ini menggunakan deskriptif persentase. Hasil dari analisis data motivasi intrinsik diketahui bahwa tidak ada peserta didik dalam kategori sangat tinggi, 8 peserta didik atau 26,67\% memiliki motivasi tinggi, 19 peserta didik atau $63,33 \%$ motivasi sedang, 3 atau $10,00 \%$ memiliki motivasi rendah, dan tidak terdapat dengan kategori sangat rendah. Sehingga rata-rata yang paling rendah yaitu indikator khawatir sebesar $3,00 \%$ dan masuk dalam kategori sedang. Motivasi ekstrinsik peserta didik diketahui bahwa tidak terdapat peserta dalam kategori sangat tinggi. 8 peserta didik atau 26,67\% memiliki motivasi tinggi, 19 peserta didik atau $63,33 \%$ memiliki motivasi sedang, 3 orang peserta didik atau $10,00 \%$ memiliki motivasi rendah, dan tidak terdapat peserta dengan kategori sangat rendah. Apabila dilihat dari deskripsi indikator data motivasi ekstrinsik nilai rata-rata yang paling rendah yaitu indikator tekanan sebesar 2,87 \% masuk dalam kategori sedang. Sehingga melalui penelitian ini, dapat diambil langkah untuk meningkatkan motivasi untuk berprestasi dibidang ektrakurikuler taekwondo.
\end{abstract}

Kata kunci: Ektrakurukuler Taekwondo, Motivasi

\begin{abstract}
This study aims to determine how much the motivation of students in taking taekwondo extracurricular activities at SMK Negeri 1 Singaraja in the 2020. This type of research is descriptive with a quantitative approach. The population in this study were 30 taekwondo extracurricular participants. The sampling technique uses a total sampling technique. Data analysis in this study used a descriptive percentage. The results of the intrinsic motivation data analysis showed that there were no students in the very high category, 8 students or $26.67 \%$ had high motivation, 19 students or $63.33 \%$ moderate motivation, 3 or $10.00 \%$ had low motivation, and there are not in the very low category. So that the average of the lowest is the worry indicator at $3.00 \%$ and it is in the medium category. The extrinsic motivation of students is known that there are no participants in the very high category. 8 students or $26.67 \%$ had high motivation, 19 students or $63.33 \%$ had moderate motivation, 3 students or $10.00 \%$ had low motivation, and there were no participants with very low categories. When viewed from the description of the extrinsic motivation data indicator, the lowest average value, namely the pressure indicator of $2.87 \%$, is in the medium category. So that through this research, steps can be taken to increase motivation to excel in the extracurricular field of taekwondo.
\end{abstract}

Key words: Taekwondo extracurricular, motivation 


\section{PENDAHULUAN}

Pendidikan jasmani merupakan bagian yang tidak terpisahkan dari pendidikan pada umumnya yang mempengaruhi potensi peserta didik dalam hal pengetahuan, sikap dan keterampilan melalui aktivitas jasmani. Pendidikan jasmani menggunakan media fisikal untuk mengembangkan kesejahteraan total setiap orang. Karakteristik pendidikan jasmani seperti ini tidak terdapat pada mata pelajaran lain, karena hasil kependidikan dari pengalaman belajar fisikal tidak terbatas hanya pada perkembangan tubuh saja. Konteks melalu aktivitas jasmani yang dimaksud ialah konteks yang utuh menyangkut semua dimensi tentang manusia, seperti halnya hubungan tubuh dan pikiran. Menurut (Bangun, 2018) menyatakan bahwa Pendidikan jasmani merupakan proses pendidikan yang memanfaatkan aktivitas jasmani yang direncanakan secara sistematik, bertujuan untuk meningkatkan individu secara organik, neuromuscular, perceptual, kognitif, sosial dan emosional.

Dalam proses pendidikan jasmani di sekolah peserta didik dituntut untuk memiliki sikap yang positif seperti disiplin, kerjasama, jujur, sportif, berperilaku baik, mentaati peraturan dan ketentuan yang berlaku. Dengan kesegaran jasmani yang baik diharapkan

dapat memberikan pengaruh yang baik pula pada peserta didik untuk dapat meningkatkan belajarnya. Dengan demikian, peserta didik akan mudah menerima setiap materi yang diberikan oleh guru. Di antara sekian banyak mata pelajaran yang diajarkan di sekolah hanya pendidikan jasmani yang berusaha mencapai tujuannya melalui aktivitas jasmani.

Pendidikan jasmani merupakan bagian yang integral dari pendidikan pada umumnya melalui aktivitas jasmani. Aktivitas jasmani yang meliputi berbagai aktivitas jasmani dan olahraga hanya sebagai alat atau sarana untuk mencapai tujuan pendidikan pada umumnya. Secara rinci tujuan pendidikan terdapat dalam UU No.20 Th. 2003 bahwa pendidikan nasional bertujuan untuk berkembangnya potensi peserta didik agar menjadi manusia yang beriman dan bertaqwa kepada Tuhan Yang Maha Esa, berakhlak mulia, sehat, berilmu, cakap, kreatif, mandiri dan menjadi warga negara yang demokratis serta bertanggung jawab

Selain itu tujuan pendidikan jasmani juga bertujuan untuk untuk mengembangkan potensi dalam diri anak baik dari segi jasmaniah maupun rohaniah (Nugroho, 2020)

Alat untuk mencapai tujuan pendidikan jasmani dalam prosesnya di wujudkan dalam dua bentuk kegiatan belajar mengajar yaitu intrakurikuler dan ekstrakurikuler. Kegiatan intrakurikuler dilaksanakan di sekolah yang pengalokasian waktunya telah ditentukan dalam struktur program. Sedangkan ekstrakurikuler yang kegiatannya dilakukan di luar jam belajar sekolah. Kegiatan ini dimaksudkan untuk mencapai tujuan pendidikan nasional yang perlu dicapai peserta didik dalam masing-masing mata pelajaran. (Muthmainnah 2019) juga menyatakan, bahwa ekstrakulikuler mampu mengembangkan berbagai potensi-potensi yang berbeda yang dimiliki peserta didik sesuai dengan minat dan bakat yang dimilikinya.

Dalam kegiatan olahraga juga terdapat berbagai jenis kegiatan ekstrakurikuler. Permendiknas no 22 tahun 2006 juga menyatakan bahwa kegiatan ekstrakurikuler sebagai kegiatan tambahan diluar struktur program yang pada umumnya merupakan program pilihan. Sedangkan ektrakurikuler olahraga adalah suatu kegiatan latihan cabang olahraga tertentu yang diakomodir sekolah. 
Sekolah harus mampu memberi wadah kepada peserta didik dan mengatur segala kegiatan-kegiatan yang berada di dalam lingkungan sekolah. Ekstrakurikuler merupakan kegiatan yang dilakukan di luar jam sekolah yang diikuti oleh peserta didik untuk menambah wawasan, pengetahuan, kemampuan termaksud untuk membantu pengembangan peserta didik sesuai dengan bakat, minat dan sesuai dengan potensi peserta didik.

Dalam

pelaksanaan

ekstrakurikuler tentunya harus di dukung dengan minat dan motivasi yang baik. Menurut Gunarsa (2008) motivasi merupakan suatu kekuatan atau tenaga pendorong untuk melakukan sesuatu hal atau menampilkan sesuatu perilaku tertentu". Hal ini bertujuan agar peserta didik tidak hanya sekedar ikut melaksanakan namun juga mampu mengikuti ekstrakurikuler sesuai dengan motivasi mereka. Besarnya motivasi peserta didik terlihat dari bagaimana perilaku dan partisipasinya dalam mengikuti suatu kegiatan. Motivasi juga berperan besar untuk mendorong peserta didik dalam melakukan suatu aktivitas tertentu, termasuk motivasi keterlibatan dalam ekstrakurikuler. Tanpa adanya motivasi dalam diri seseorang maka dia tidak akan tertarik untuk melakukan apapun. Motivasi ini yang mendorong seseorang untuk melakukan suatu hal dengan kesadaran sendiri bahkan memacu dirinya untuk berprestasi. Dengan demikian, pesertadidik sangat membutuhkan motivasi yang memacu dirinya untuk berprestasi dalam bidang yang diminatinya.

Sebagai salah satu sekolah di Singaraja yang memiliki wadah ekstrakulikuler bagi peserta didiknya, SMK Negeri 1 Singaraja juga memberi kesempatan kepada peserta didiknya untuk terlibat dalam ekstrakurikuler taekwondo bagi yang memiliki minat dibidang tersebut. Minat dan kegemaran siswa dalam mengikuti kegiatan ekstrakulrikuler taekwondo dipengaruhi oleh adanya motivasi. Aspek motivasi memegang peranan dalam kejiwaan seseorang, sebab motivasi merupakan salah satu faktor penentu sebagai pendorong tingkah laku manusia, sehingga dengan adanya motivasi seseorang dapat mendorong dirinya untuk lebih giat berlatih dan mencapai hasil yang maksimal. Dengan adanya motivasi tersebut akan mendorong seseorang untuk berlatih, bekerja keras, dan dapat bertahan lebih lama dalam megikuti suatu kegiatan atau latihan. Adapun Jenis kegiatan ekstrakurikuler sangat beragam, antara lain kegiatan kerohanian, olahraga, seni, pramuka, dan lain-lain.

Berdasarkan hasil wawancara yang dilakukan, bahwa tahun-tahun sebelumnya terdapat banyak peserta didik yang mengikuti kegiatan ekstrakurikuler taekwondo dengan prestasi yang signifikan juga. Sedangkan untuk saat ini hasil observasi yang dilakukan oleh penulis di SMK Negeri 1 Singaraja menunjukkan bahwa saat ini terdapat 30 peserta didik yang tergabung dalam ekstrakulikuler taekwondo. Jumlah tersebut memang cukup banyak untuk jenis olahraga bela diri. Ketersediaan fasilitas yang disediakan dan adanya pendampingan yang diberikan oleh pelatih yang disediakan sekolah, serta program latihan yang dilakukan secara rutin tentu akan mempengaruhi kualitas ekstrakulikuler ini di SMK Negeri 1 Singaraja. Namun, SMK Negeri 1 Singaraja belum menunjukkan banyak prestasi. Memang ada beberapa kejuaraan yang berhasil diraih oleh ekstrakulikuler taekwondo SMK Negeri 1 Singaraja seperti salah satunya pada ajang kejuaraan bulldog taekwondo championship 2019, tetapi hasil tersebut belum signifikan jika dibandingkan dengan jumlah peserta didik yang tergabung didalam ekstrakulikuler ini.

Penelitian yang sama pernah dilakukan ole Rahmayadi Ulfa, dkk (2020) dengan judul "Motivasi Siswa Dalam Mengikuti Kegiatan Ekstrakurikuler Pencak Silat. Jenis 
penelitian ini adalah deskriptif dengan teknik analisis data menggunakan deskriptif persentatif. Hasil penelitian ini adalah Motivasi siswa dalam mengikuti kegiatan ekstrakurikuler silat di SMA Negeri 1 Tanjung Mutiara Kabupaten Agam berada pada kategori baik dengan persentase 76,04\%. Perbedaannya dengan penelitian saat ini adalah terletak pada tujuannya. Dimana penelitian tersebut bertujuan untuk mengetahui bagaimana motivasi siswa SMA Negeri 1 Tanjung Mutiara Kabupaten Agam dalam mengikuti ekstrakurikuler pencak Silat sedangkan penelitian saat ini bertujuan untuk mengetahui motivasi pada ekstrakurikuler taekwondo.

(Samsudin 2019) juga melakukan penelitian serupa dengan judul "Pengaruh Motivasi Siswa Dalam Mengikuti Ekstrakurikuler Bolavoli di SMP Negeri 13 Kota Bekasi". Penelitian ini merupakan penelitian kuantitatif dengan metode analisis deskriptif presentase, sedangkan metode pengumpulan data yang digunakan oleh peneliti adalah angket/kuesioner. Penelitian ini bertujuan untuk mengetahui motivasi peserta didik dalam mengikuti ekstrakurikuler bola voli sedangkan penelitian saat ini bertujuan untuk mengetahui motivasi pada ekstrakurikuler taekwondo.

Latar berlakang diatas menunjukkan bahwa keberhasilan sebuah program ekstrakurikuler ditentukan oleh berbagai faktor, diantaranya fasilitas, program latihan, pelatih serta motivasi peserta didik. Dari sekian banyak faktor yang ada, penulis ingin melakukan penelitian mengenai motivasi peserta didik yang mungkin menjadi salah satu penyebab kurang optimalnya kegiatan ekstrakurikuler taekwondo di SMK Negeri 1 Singaraja. Maka dalam hal ini penulis bermaksud untuk membuat penelitian dengan judul "Motivasi Peserta Didik Dalam Mengikuti Ekstrakulikuler Taekwondo di SMK Negeri 1 Singaraja Tahun Pelajaran 2020/2021". Penelitian ini diharapkan untuk menggali masalah yang terjadi dalam ekstrakurikuler taekwondo ini dan menemukan solusi untuk mengatasi permasalahan tersebut sehingga akan tercipta ekstrakurikuler taekwondo sesuai dengan harapan.

\section{METODE}

Penelitian ini merupakan penelitian deskriptif kuantitatif. Menurut (I Nyoman Kanca 2015) menyatakan bahwa penelitian deskriptif adalah suatu metode dalam meneliti sekelompok manusia, atau obyek tertentu dengan tujuan untuk membuat deskripsi, gambaran secara sistematis, faktual dan akurat mengenai fakta-fakta,sifat-sifat hubungan antar fenomena yang diselidiki. Sedangkan Menurut Sugiyono (2009: 22), penelitian deskriptif kuantitatif adalah penelitian yang bertujuan memberikan gambaran terhadap objek yang diteliti melalui data sampel atau populasi yang dinyatakan dalam bentuk angka. Metode yang digunakan dalam penelitian ini adalah metode survei. Penelitian ini dilakukan di SMK Negeri 1 Singaraja, khusunya pada peserta didik yang mengikuti ekstrakurikuler taekwondo tahun pelajaran 2020/2021. Penelitian motivasi peserta didik dalam mengikuti ekstrakurikuler taekwondo di SMK Negeri 1 Singaraja merupakan penelitian kuantitatif dengan jenis pendekatan survei. Survei itu sendiri tujuannya untuk memperoleh gambaran umum tentang karakteristik populasi. Adapun jenis survei yang digunakan dalam penelitian ini adalah survei deskriptif. Hal ini dimaksudkan untuk menghimpun data tentang motivasi peserta didik terhadap ekstrakurikuler taekwondo. Berdasarkan tujuan penelitian tersebut, maka metode penelitian yang digunakan adalah metode penelitian survei dengan instrumen berupa angket.

Teknik analisi data yang digunakan adalah analisis data diskriptif dengan persentase dari jawaban peserta didik. Penghitungan statistikdeskriptif menggunakan statistik deskriptif 
persentase, karena yang termasuk dalam statistik deskriptif antara lain penyajian data melalui tabel, perhitungan mean, median, perhitungan penyebaran data perhitungan rerata-

\section{HASIL DAN PEMBAHASAN}

Tempat penelitian ini dilakukan di SMK Negeri 1 Singaraja, Kecamatan buleleng, Kabupaten Buleleng, Provensi Bali. Penelitian ini dilaksanakan bulan September 2020. Subjek pada penelitian ini melibatkan seluruh peserta didik yang mengikuti kegiatan ekstrakurikuler taekwondo di SMK Negeri 1 Singaraja adapun jumlah populasi dalam penelitian ini yakni 30 peserta didik anatara. Pengambilan sampel pada penelitian melibatkan keseluruhan Peserta didik yang

Terdapat dua faktor yang perlu diamati terhadap motivasi peserta didik dalam mengikuti ekstrakurikuler taekwondo yaitu faktor intrinsik dengan indikator tekun, rajin, displin, takut dan khawatir. Sedangkan faktor ekstrinsiknya yaitu hadiah, rata skor, stadar devisiasi, dan persentase. Pengkategorian menggunakan Mean dan Standar Deviasi.

mengikuti ekstrakurikuler taekwondo. Pengambilan data pada penelitian ini di laksanakan dengan teknik daring dengan menggunakan bantuan google form.

Variabel bebas dalam penelitian ini adalah motivasi peserta didik, sementara variabel terikatnya adalah ekstrakurikuler taekwondo. Data hasil penelitian ini didapatkan melalui jawaban responden di dalam kuisioner. Sebelum data motivasi peserta didik dianalisis, data tersebut perlu untuk dideskripsikan untuk memudahkan penyajian data penelitian.

penghargaan, hukuman dan tekanan. Berikut adalah hasil dari analisis deskritif data motivasi peserta didik dalam mengikuti kegiatan ekstrakurikuler taekowondo di SMK Negeri 1 Singaraja yang disajikan dalam tabel.

Tabel 1. Deskripsi Data Motivasi Intrinsik

\begin{tabular}{llllll}
\hline No & Data & Minimum & $\begin{array}{l}\text { Maksimu } \\
\mathbf{m}\end{array}$ & $\begin{array}{l}\text { Rata- } \\
\text { rata }\end{array}$ & $\begin{array}{l}\text { Standar } \\
\text { Deviasi }\end{array}$ \\
\hline 1 & Tekun & 2.67 & 4.00 & 3.24 & Sedang \\
2 & Rajin & 2.60 & 3.47 & 3.05 & Sedang \\
3 & Disiplin & 2.63 & 3.50 & 3.14 & Sedang \\
4 & Takut & 2.73 & 3.83 & 3.32 & Sedang \\
5 & Khawatir & 2.57 & 3.43 & 3.00 & Sedang
\end{tabular}

Berdasarkan tabel 4.1 diketahui bahwa motivasi intrinsik dalam mengikuti kegiatan ekstrakurikuler taekwondo di SMK Negeri 1 Singaraja diamati dari beberapa indikator yaitu indikator tekun, rajin, disiplin, takut dan khawat 
Tabel 2. Deskripsi Motivasi Ekstrinsik

\begin{tabular}{clcccc}
\hline No & \multicolumn{1}{c}{ Data } & $\begin{array}{c}\text { Nilai } \\
\text { Minimum }\end{array}$ & $\begin{array}{c}\text { Nilai } \\
\text { Maksimum }\end{array}$ & Rata-rata & Keterangan \\
1 & Hadiah & 2.53 & 3.83 & 3.17 & Sedang \\
2 & Penghargaa & 2.07 & 3.43 & 3.17 & Sedang \\
& n & & & & Sedang \\
3 & Hukuman & 2.47 & 3.90 & 3.07 & Sedang \\
\hline
\end{tabular}

Berdasarkan tabel 2 diketahui bahwa motivasi ekstrinsik dalam mengikuti kegiatan ekstrakurikuler taekwondo di SMK Negeri 1 Singaraja diamati dari beberapa indikator yaitu indikator hadiah, penghargaan, hukuman dan tekanan.

Data penelitian motivasi peserta didik dalam mengikuti ekstrakurikuler taekwondo dianalisis menggunakan teknik analis deskriptif persentase. Data dalam penelitian ini dibagi menjadi
5 kategori antara lain: sangat tinggi, tinggi, sedang, rendah dan sangat rendah. Pengkategorian tersebut dibuat berdasarkan mean ideal dan standar deviasi ideal yang merupakan hasil perhitungan deskriptif yang telah dilakukan sebelumnya. Motivasi peserta didik dalam mengikuti ekstrakurikuler taekwondo di SMK Negeri 1 Singaraja diukur menggunakan angket yang terdiri dari 45 pernyataan. Dari hasil analisis data yang telah dilakukan, maka diperoleh hasil sebagai berikut.

Tabel 3. Motivasi Intrinsik Peserta Didik Dalam Mengikuti Ekstrakurikuler Taekwondo Di SMK Negeri 1 Singaraja

\begin{tabular}{cccc}
\hline RANGE & FREKUENSI & PERSENTASE $\%$ & KATEGORI \\
$4,01-5$ & 0 & - & $\mathrm{ST}$ \\
$3,34-4$ & 8 & 26.67 & $\mathrm{~T}$ \\
$2,67-3,33$ & 19 & 63.33 & $\mathrm{~S}$ \\
$2-2,66$ & 3 & 10.00 & $\mathrm{R}$ \\
$1-1,99$ & 0 & - & $\mathrm{SR}$ \\
\hline
\end{tabular}

Berdasarkan tabel 3 motivasi intrinsik peserta didik dalam mengikuti ekstrakurikuler taekwondo di SMK Negeri 1 Singaraja tahun pelajaran 2020/2021 yang terdiri dari beberapa indikator yaitu tekun, rajin, displin, takut dan khawatir. Diketahui bahwa tidak ada peserta didik yang tergolong dalam katagori motivasi sangat tinggi. 8 orang peserta didik atau $26,67 \%$ memiliki motivasi tinggi, 19 orang peserta didik atau $63,33 \%$ memiliki motivasi sedang, 3 orang peserta didik atau $10,00 \%$ memiliki motivasi rendah,

sedangkan untuk katagori sangat rendah tidak ada peserta didik. Apabila dilihat dari frekuensi yang muncul pada tiap kategori, maka dapat diketahui motivasi intrinsik peserta didik dalam mengikuti kegiatan ekstrakurikuler taekwondo SMK Negeri 1 Singaraja berada dalam kategori sedang. 
Tabel 4. Motivasi Ekstrinsik Peserta Didik Dalam Mengikuti Ekstrakurikuler Taekwondo di SMK Negeri 1 Singaraja Tahun 2020

\begin{tabular}{cccc} 
RANGE & FREKUENSI & PERSENTASE $\%$ & KATEGORI \\
$4,01-5$ & 0 & - & ST \\
$3,34-4$ & 9 & 30.00 & $\mathrm{~T}$ \\
$2,67-3,33$ & 15 & 50.00 & $\mathrm{~S}$ \\
$2-2,66$ & 6 & 20.00 & $\mathrm{R}$ \\
$1-1,99$ & 0 & - & $\mathrm{SR}$ \\
\hline
\end{tabular}

Berdasarkan tabel 4 motivasi ekstrinsik peserta didik dalam mengikuti ekstrakurikuler taekwondo di SMK

Negeri 1 Singaraja tahun 2020 yang terdiri dari beberapa indikator yaitu hadiah, penghargaan, hukuman dan tekanan. Diketahui bahwa tidak ada peserta didik yang memiliki motivasi sangat tinggi terhadap ekstrakurikuler taekwondo, 9 peserta didik atau 30,00\% memiliki motivasi tinggi, 15 peserta didik atau $50,00 \%$ memiliki motivasi sedang, 6 peserta didik atau 20,00\% memiliki motivasi rendah, sedangkan tidak terdapat peserta didik dengan kategori sangat rendah terhadap motivasi ekstrakurikuler taekwondo. Apabila dilihat dari jumlah persentase yang muncul pada tiap kategori, maka dapat diketahui bahwa dapat diketahui motivasi ekstrinsik peserta didik dalam mengikuti kegiatan ekstrakurikuler taekwondo SMK Negeri 1 Singaraja berada dalam kategori sedang.

Penelitian ini dilakukan bertujuan untuk mengetahui seberapa besar motivasi peserta didik dalam mengikuti ekstrakurikuler taekwondo di SMK Negeri 1 Singaraja. Menurut Moekijat (2002), "motivasi adalah suatu daya pendorong atau perangsang untuk melakukan sesuatu". Oleh karena itu, motivasi merupakan sesuatu hal yang sangat penting dalam proses pembelajaran. Untuk mengetahui seberapa besar motivasi peserta didik dalam mengikuti ekstrakurikuler taekwondo di SMK Negeri 1 Singaraja maka dalam penelitian ini pengambilan data menggunakan angket. Analisis data yang dilakukan secara deskriptif persentase. Setelah melakukan analisis deskriptif persentase maka diketahui motivasi intrinsk dan ekstrinsik peserta didik dalam mengikuti ekstrakurikuler taekwondo di SMK Negeri 1 Singaraja tahun 2020.

Hasil dari analisis data motivasi intrinsik diketahui bahwa tidak ada peserta didik yang tergolong dalam katagori motivasi sangat tinggi, 8 orang peserta didik atau $26,67 \%$ memiliki motivasi tinggi, 19 orang peserta didik atau $63,33 \%$ memiliki motivasi sedang, 3 orang peserta didik atau 10,00\% memiliki motivasi rendah, sedangkan untuk katagori sangat rendah tidak ada peserta didik. Apabila dilihat dari deskripsi indikator data motivasi intrinsik nilai rata-rata yang paling rendah yaitu indikator khawatir sebesar 3,00\% masuk dalam katagori sedang. Bila dilihat dari frekuensi yang muncul pada tiap kategori, maka dapat diketahui bahwa pengaruh terbesar yang menyebabkan kurangnya motivasi intrinsik peserta didik adalah indikator khawatir. Rasa khawatir pada seseorang akan membawa pengaruh buruk bagi orang tersebut saat hendak mencapai sebuah tujuan. Lestari, dkk (2020) juga menyampaikan bahwa khawatir merupakan suatu bentuk perasaan yang kurang menyenangkan. Rasa khawatir dapat membuat seseorang menjadi tidak focus serta tidak maksimal saat melakukan sesuatu untuk mencapai tujuannya.

Hasil analisis data motivasi ekstrinsik peserta didik diketahui bahwa tidak ada peserta didik yang tergolong dalam katagori motivasi sangat tinggi. 8 orang peserta didik atau $26,67 \%$ memiliki motivasi tinggi, 19 orang 
peserta didik atau $63,33 \%$ memiliki motivasi sedang, 3 orang peserta didik atau $10,00 \%$ memiliki motivasi rendah, sedangkan untuk katagori sangat rendah tidak ada peserta didik. Apabila dilihat dari deskripsi indikator data motivasi ekstrinsik nilai rata-rata yang paling rendah yaitu indikator tekanan sebesar $2,87 \%$ masuk dalam katagori sedang. Indikator tekanan inilah yang menjadi penyebab terbesar kurangnya motivasi ekstrinsik peserta didik dalam mengikuti kegiatan ekstrakurikuler taekwondo. Pada tingkat tertentu tekanan dapat mendorong atau memotivasi untuk meningkatkan produktivitas. Namun bila tekanan yang timbul berlebih dan tidak mampu untuk dikendalikan oleh diri sendiri maka akan berakibat buruk baik secara mental ataupun fisik. Hal ini juga disampaikan oleh Rahmawati, (2017) dimana tekanan menjadi salah satu yang paling berpengaruh pada pencapaian prestasi seseorang.

Hasil analisis menunjukkan bahwa motivasi intrinsik peserta didik berada dalam katagori sedang dan motivasi ekstrinsik peserta didik berada dalam katagori sedang juga. Sejalan dengan penelitian (Styowati Hamidatin dan Hariyati, 2018), yang berjudul "Motivasi Peserta Didik Dalam Mengikuti Ekstrakurikuler Keperamukaan di SMP Negeri 46 Surabaya". Hasil penelitian ini motivasi peserta didik dalam mengikuti ekstrakurikuler kepramukaan di SMP Negeri 46 Surabaya dalam kategori sedang dengan persentase 38\% sebanyak 199 anak. Data lebih spesifik mengenai aspek-aspek motivasi, diperoleh data bahwa motivasi akan afiliasi tergolong tinggi dengan persentase sebesar $34,9 \%$ sebanyak 183 anak. Sedangkan, motivasi akan prestasi dengan persentase sebesar $34,5 \%$ sebanyak 181 anak dan aspek kekuasaan juga tergolong sedang dengan persentase sebesar 30\% sebanyak 157 anak. Penelitian yang sama dilakukan oleh (Candra Dewi, 2020), yang berjudul "Motivasi
Mahasiswa Prodi Pendidikan Jasmani Kesehatan Dan Rekreasi Menjaga Kebugaran Jasmani Pada Masa Pandemi Covid-19" Hasil analisis dalam penelitian ini menyatakan bahwa motivasi intriksik mendapatkan skor $86 \%$ dan motivasi ekstrinsik mendapatkan skor $80 \%$ dalam skala penilaian katagori dinyatakan sangat tinggi. Dari kedua indikator pada variabel motivasi memperoleh skor $83 \%$ pada interval katagori dikatakan sangat tinggi. Saran dari peneliti untuk mahasiswa agar meningkatkan motivasi untuk melaksanakan aktivitas (Yasa dan Artanayasa, 2020) yang berjudul "Motivasi Atlet Club Renang Di Kabupaten Badung Dalam Menjaga Kebugaran Jasmani Pada Masa Pandemi Covid-19" Hasil dari penelitian motivasi atlet club renang di kabupaten Badung dalam menjaga kebugaran jasmani pada masa pandemi covid-19 pada faktor intrinsik yaitu 83 dan pada faktor ekstrinsik mendapat skor 81. Dari kedua faktor tersebut motivasi atlet club renang di Kabupaten Badung dalam menjaga kebugaran jasmani pada masa pandemi covid-19 mendapat skor 82 dalam sekala penelitian katagori sangat tinggi. Saran dari peneliti untuk atlet agar menjadi lebih termotivasi dalam menjaga kebugaran jasmani meskipun ditengah pandemi harus berusaha mencari untuk meningkatkan kebugaran jasmani pada masa pandemi covid-19.

(Putra pratama,dkk. 2020) yang berjudul "Motivasi Peserta Didik Smk Triatmajaya Singaraja Menjaga Kebugaran Jasmani Pada Masa Pandemi Covid-19" Hasil dari penelitian ini yaitu pada faktor intrinsik motivasi peserta didik SMK Triatmajaya Singaraja dalam menjaga kebugaran jasmani pada masa pandemi covid-19 memperoleh skor 79,5 jika dikonversikan ke dalam interval kategori termasuk dalam kategori sangat tinggi. Sedangkan pada faktor ekstrinsik motivasi peserta didik SMK Triatmajaya Singaraja dalam menjaga kebugaran jasmani pada masa pandemi covid-19 
memperoleh skor 7,44 jika dikonversikan ke dalam interval kategori termasuk dalam kategori sangat tinggi.

Berdasarkan kedua indikator pada variabel, motivasi peserta didik SMK Triatmajaya Singaraja dalam menjaga kebugaran jasmani pada masa pandemi covid-19 memperoleh skor 76,9. Jika dikonversikan ke dalam interval kategori, motivasi peserta didik SMK Triatmajaya Singaraja menjaga kebugaran jasmani pada masa pandemi covid-19 termasuk dalam kategori sangat tinggi. Dengan demikianpeserta didik SMK Triatmajaya Singaraja bisa menjadi contoh untuk peserta didik yang lain agar dapat menjaga dan melaksanakan aktivitas kebugaran jasmani pada masa pandemi covid-19 serta menigkatkan kekebalan tubuh.

Penelitian-penelitian terdahulu ini berkaitan dengan penelitian saat ini. Hal ini dapat terlihat bahwa motivasi menjadi suatu pengaruh besar untuk seseorang mewujudkan tujuan yang diharapkan. Tujuan yang dimaksud pada hal ini ialah dalam bidang ekstrakurikuler olahraga. Semakin tinggi motivasi dalam diri seseorang maka akan semakin besar peluang untuk memperoleh tujuannya. Demikian juga sebaliknya, semakin kecil motivasi seseorang maka akan semakin kecil pula peluangnya untuk mewujudkan impiannya.

Motivasi peserta didik dalam mengikuti ekstrakurikuler taekwondo dipengaruhi oleh dua faktor yaitu faktor intrinsik dan ekstrinsik. Adapun faktor intrinsik tersebut meliputi tekun, rajin, disiplin, takut dan khawatir. Sedangkan faktor ekstrinsik yaitu hadiah, penghargaan, hukuman dan tekanan. Faktor intrinsik dan ekstrinsik ini sangat mempengaruhi tingkat motivasi peserta didik dalam mengikuti ekstrakurikuler taekwondo. Berdasarkan hasil analisis yang dilakukan, dapat diketahui penyebab dari tidak maksimalnya prestasi peserta didik di bidang taekwondo lebih dipengaruhi oleh motivasi intrinsik. Hasil akhir ini sesuai dengan pembahasan pada latar belakang penelitian ini. Dimana prestasi peserta didik dalam kegiatan ekstrakurikuler taekwondo tidak signifikan dengan jumlah peserta didik yang mengikuti ekstrakurikuler tersebut.

\section{SIMPULAN DAN SARAN}

Berdasarkan hasil analisis data dan pembahasan dapat diambil kesimpulan, bahwa motivasi peserta didik dalam mengikuti kegiatan ekstrakurikuler taekwondo di SMK Negeri 1 Singaraja tahun 2020 adalah "sedang".

Dari hasil dan pembahasan pada penelitian ini di harapkan dapat berguna bagi pihak sekolah baik guru atau pelatih untuk mendorong peserta didik lebih termotivasi dalam mengikuti kegiatan ekstrakurikuler taekwondo.

\section{DAFTAR PUSTAKA}

Ariesta, Dofi Bellavia. 2014. Seni Beladiri Taekwondo. Jakarta. Golden Terayon Press

Gunarsa, Singgih. 2008. Psikologi Olahraga Prestasi. Jakarta: PT BPK Gunung Mulia.

Kirom Askhabul. 2017. "Peran Guru Dan Peserta Didik Dalam Proses Pembelajaran Berbasis Multikultural". Volume 3, Nomor 1.

Malasari, Citra Azhariat. (2019). "Pengaruh Latihan Shuttle-Run Dan Zig-Zag Run Terhadap Kelincahan Atlet Taekwondo". Jurnal Pendidikan Jasmani dan Olahraga Volume 3, Nomor 1.

Muthmainnah, Heny Tri.2019. Peran Kepala Sekolah Sebagai Manajer Dalam Meningkatkan Mutu Ekstrakulikuler Futsal. Tugas Akhir (tidak diterbitkan). Jurusan PGSD Fakultas Keguruan dan IImu Pendidikan, Universitas Muhhamadiyah Surakarta. 
Moekijat.2002.Dasar-dasar

Motivasi.Bandung. Penior Jaya

Mylsidayu, Apta. 2014. Psikologi Olahraga. Jakarta : Bumi Aksara.

Yahya dan Amirzan. 2019. "Tanggapan Siswa Terhadap Manfaat Kegiatan Ekstrakurikuler Olahraga Dalam Pengembangan Prestasi Dan Potensi Diri ". Jurnal Sosial Humaniora, Volume 2, Nomor 1, April 2019

Santrock, Jhon W. 2004. Psikologi Pendidikan. Jakarta. Kencana

Setianto Wahid Rohmat, Dkk.(2017). "Pengembangan Latihan Taekwondo Dengan Media Audio-Visual Untuk Ekstrakurikuler Taewkondo di SMA Kabupaten Tulungagung". Gelanggang Pendidikan Jasmani Indonesia, Volume 1 , Nomor 1, Tahun 2017, Halaman $30-39$

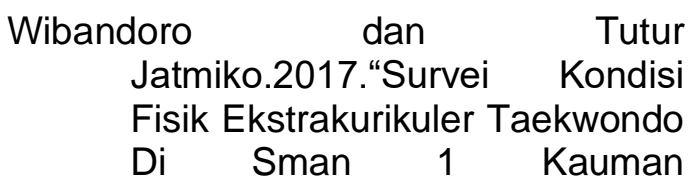

Tulungagung". Jurnal Prestasi Olahraga

Bangun M.Wanda Aginta. 2018. "Pemanfaatan hasil modifikasi pembelajaran pendidikan jasmani di slb-ypac cabang medan". Journal Physical Education, Health and Recreation. Volume 2 Nomor 2

Tasrim dan Elihami. 2018. "Motivasi Kerja Pendidik Dalam Meningkatkan Manajemen Lembaga Pendidik Dasar" Jurnal Pendidikan Guru Sekolah Dasar

Annas, Anisa Nuraisyah. 2017. "Manajemen Peserta Didik Berbasis Kecerdasan Spiritual Pendidikan Islam". Jurnal Manajemen Pendidikan Islam. Volume 5 Nomor 2

Kurnia dan Hamida. 2020. "Pengaruh Latihan Jogging Terhadap Daya Tahan Kardiorespirasi Pada Atlet Taekwondo Survivar 5 Club Palembang" Jurnal IImu Keolahragaan, Vol 3 